\title{
EVOLUTION OF THE SCIENTIFIC-ORGANIZATIONAL FOUNDATIONS OF ORGANIC FARMING IN UKRAINE: HISTORIOGRAPHY OF THE INDEPENDENCE PERIOD
}

\section{Volodymyr Orekhivskyi}

\section{INTRODUCTION}

The historiography of the evolution of the scientific-organizational foundations of organic farming has a long tradition. Due to the development of thinking and the latest scientific approaches, historical works on the problem of research are divided in chronological principle into two groups. The first of these includes scientific publications published in the Soviet era, and the second - during the independence of Ukraine ${ }^{1}$. They differ in principled approaches, ideological content, provisions and conclusions, since researchers of the history of agrarian science worked in different socio-economic and socio-political conditions of certain historical periods. An independent period in historiography began in independent Ukraine in search of new conceptual approaches to the historical knowledge of world and regional alternative measures ${ }^{2}$. Historiography has begun to play the role of an integration factor, maintaining an appropriate level of knowledge regarding the development of environmentally friendly technologies in Ukraine ${ }^{3}$.

\footnotetext{
1 Orekhivskyi, V. D. (2017) Evoliutsiia naukovykh osnov orhanichnoho zemlerobstva $v$ Ukraini (druha polovyna XIX - pochatok XXI st.): monohrafiia [Evolution of the scientific basis of organic agriculture in Ukraine (the second half of XIX is beginning of XXI of century): monograph]. Vinnytsia: TOV «Nilan-LTD», p. 12. (in Ukrainian).

2 Kovalenko, N. P. (2014) Stanovlennia ta rozvytok naukovo-orhanizatsiinykh osnov zastosuvannia vitchyznianykh sivozmin u systemakh zemlerobstva (druha polovyna XIX-pochatok XXI st.): monohrafiia [Becoming and development of scientifically-organizational bases of application of home crop rotations in the systems of agriculture (the second half of XIX is beginning of XXI of century): monograph]. Kyiv: TOV «Nilan-LTD», p. 17. (in Ukrainian).

Kovalenko, N. P. (2017) Zarodzhennia naukovykh osnov orhanichnoho zemlerobstva $v$ Ukraini $u$ XVIII - pershii polovyni XIX stolit [The emergence of the
} 
In modern domestic science, there has been an expansion of historical publications that reproduce the history of the formation and development of science and research in the field of organic agriculture of Ukraine. In particular, the evolution of particular scientific trends, theories, concepts and technologies in organic farming. Contribution to the development of scientific technologies of organic farming of higher education institutions, research institutions and research teams; the evolution of the scientific foundations of organic farming in the context of the activities of well-known agrarian scientists; development of practical introduction of organic farming in organic production enterprises in Ukraine ${ }^{4}$. They contain systematic factual material on the development of theoretical-methodological foundations and practical application of organic farming in Ukraine, a thorough analysis of scientific technologies and their theoretical generalizations.

To study the formation and development of organic farming in independent Ukraine, it was important to summarize the scientific achievements of researchers, identify conflicting, as well as insufficiently disclosed aspects that need further elaboration ${ }^{5}$. Therefore, the comprehensive coverage of historiography on the evolution of the scientific and organizational foundations of organic farming in the period of Ukraine's independence is of great importance. In particular, it is crucial to identify and analyze fundamental research on the history of the formation and development of theoretical, methodological and scientific-practical foundations of organic agriculture in different soil and climatic conditions of independent Ukraine.

scientific foundations of organic farming in Ukraine in the XVIII - first half of the XIX centuries]. Visnyk ahrarnoi istorii, vol. 19-20, p. 201. (in Ukrainian).

4 Orekhivskyi, V. D. (2017) Evoliutsiia naukovykh osnov orhanichnoho zemlerobstva $v$ Ukraini (druha polovyna XIX - pochatok XXI st.): monohrafiia [Evolution of the scientific basis of organic agriculture in Ukraine (the second half of XIX is beginning of XXI of century): monograph]. Vinnytsia: TOV «Nilan-LTD», p. 13. (in Ukrainian).

${ }^{5}$ Kovalenko, N. P. (2017) Evoliutsiia naukovykh osnov orhanichnoho zemlerobstva $v$ Ukraini $u$ druhii polovyni XIX - na pochatku XXI stolit [The evolution of the scientific foundations of organic farming in Ukraine in the second half of the XIX - at the beginning XXI centuries]. Visnyk ahrarnoi istorii, vol.21-22, p. 259. (in Ukrainian). 


\section{The formation of theoretical-methodological foundations of organic farming in the historiography of independent Ukraine}

One of the first publications of agrarian directions on improvement of ecologically safe measures in organic farming were the works of P. I. Boyko, N. P. Kovalenko, which describes the evolution of theoretical aspects of biological biology of agriculture from ancient times. They analyzed the history, current state and prospects of the development of farming systems and crop rotation ${ }^{6}$, identified the historical and modern achievements of their research and implementation $^{7}$, determined the effectiveness of steam use in the past and present agriculture of Ukraine ${ }^{8}$. They reveal the history of formation and development of one of the basic links of organic farming - scientifically based crop rotations. The gradual improvement of alternation of crops with different biological properties and agrotechnics - cereals, technical, fodder, vegetables, as well as steam, the use of effective precursors and permissible periods of return to the previous place of cultivation was analyzed ${ }^{9}$.

It should be noted that a comprehensive historical study of N. P. Kovalenko on the formation and development of scientific and organizational foundations of the use of one of the main links of organic farming - scientifically substantiated crop rotations in the systems of agriculture during the second half of the $19^{\text {th }}$ and early $21^{\text {st }}$

6 Boiko, P. I. \& Kovalenko, N. P. (2004) Systemy zemlerobstva ta sivozminy: istoriia, suchasnyi stan $i$ perspektyvy rozvytku [Systems of agriculture and crop rotation: history, current state and prospects for development]. Visnyk Poltavskoi derzhavnoi ahrarnoi akademii, vol. 3, pp. 21-26. (in Ukrainian).

7 Boiko, P. I. \& Kovalenko, N. P. (2005) Istorychni $i$ suchasni dosiahnennia $u$ vyvchenni ta vprovadzhenni system zemlerobstva $i$ sivozmin [Historical and contemporary achievements in the study and implementation of farming systems and crop rotations]. Ahronom, no. 3, pp. 78-81. (in Ukrainian).

8 Boiko, P. I. \& Kovalenko, N. P. (2008) Pary $v$ proshlom y sovremennom zemledelyy [Pairs in past and present agriculture]. Ahrovisnyk Ukraina. no. 2. pp. 14-17. (in Russia).

9 Orekhivskyi, V. D. (2017) Evoliutsiia naukovykh osnov orhanichnoho zemlerobstva $v$ Ukraini (druha polovyna XIX - pochatok XXI st.): monohrafiia [Evolution of the scientific basis of organic agriculture in Ukraine (the second half of XIX is beginning of XXI of century): monograph]. Vinnytsia: TOV «Nilan-LTD», p. 313. (in Ukrainian). 
centuries $^{10}$. The researcher, based on historical-scientific analysis, reproduced the evolution of crop rotation and other ecologically safe agrotechnical measures in the agriculture of Ukraine, suggested the periodization of their formation and development, determined the contribution of higher education institutions, research institutions, theorists and practitioners in this process. Considerable attention was paid to the formation and development of scientific schools for the improvement of ecologically safe agrotechnical measures in agriculture of different soil and climatic conditions of Ukraine ${ }^{11}$.

The evolution of organic farming in Ukraine is of great importance in the publications of N. P. Kovalenko, where the subject of research was the scientific-organizational and conceptual foundations of the development of ecologically balanced crop rotation in systems of alternative agriculture $^{12}$. In addition, the researcher analyzed the origin of scientific foundations of organic farming in Ukraine in the $18^{\text {th }}$ - first half of the $19^{\text {th }}$ century ${ }^{13}$, their evolutionary changes in the second half of the $19^{\text {th }}$ and early $21^{\text {st }}$ centuries $^{14}$. In particular, the efficiency of growing

10 Kovalenko, N. P. (2014) Stanovlennia ta rozvytok naukovo-orhanizatsiinykh osnov zastosuvannia vitchyznianykh sivozmin u systemakh zemlerobstva (druha polovyna XIX-pochatok XXI st.): monohrafiia [Becoming and development of scientifically-organizational bases of application of home crop rotations in the systems of agriculture (the second half of XIX is beginning of XXI of century): monograph]. Kyiv: TOV «Nilan-LTD», 490 s. (in Ukrainian).

Orekhivskyi, V. D. (2017) Evoliutsiia naukovykh osnov orhanichnoho zemlerobstva $v$ Ukraini (druha polovyna XIX - pochatok XXI st.): monohrafiia [Evolution of the scientific basis of organic agriculture in Ukraine (the second half of XIX is beginning of XXI of century): monograph]. Vinnytsia: TOV «Nilan-LTD», p. 19. (in Ukrainian).

12 Kovalenko, N.P. (2012) Ekolohichno zbalansovani sivozminy $v$ systemi alternatyvnoho zemlerobstva: istorychni aspekty [Ecologically balanced crop rotation in the system of alternative agriculture: historical aspects]. Ahroekolohichnyi zhurnal, no. 4, pp. 95-99. (in Ukrainian).

13 Kovalenko, N. P. (2017) Zarodzhennia naukovykh osnov orhanichnoho zemlerobstva $v$ Ukraini $u$ XVIII - pershii polovyni XIX stolit [The emergence of the scientific foundations of organic farming in Ukraine in the XVIII - first half of the XIX centuries]. Visnyk ahrarnoi istorii, vol. 19-20, pp. 200-216. (in Ukrainian).

14 Kovalenko, N. P. (2017) Evoliutsiia naukovykh osnov orhanichnoho zemlerobstva $v$ Ukraini $u$ druhii polovyni XIX - na pochatku XXI stolit [The evolution of the scientific foundations of organic farming in Ukraine in the second half of the XIX - at the beginning XXI centuries]. Visnyk ahrarnoi istorii, vol. 21-22, pp. 258-268. (in Ukrainian). 
leguminous and sidereal crops in crop rotation, grassland, the use of postharvest and post-cultivation crops, by-products, the use of organic fertilizers and rational cultivation of soil ${ }^{15}$. In the scientific works of N. P. Kovalenko the historical aspects of the origin and development of scientific and organizational foundations of different types of crop rotations - sidereal $^{16}$, grassland ${ }^{17}$, the evolution of scientific views on allelopathic activity of crops in crop rotation ${ }^{18}$ are analyzed.

Noteworthy are the scientific publications devoted to the evolution of theoretical-methodological foundations of different directions of greening agriculture in Ukraine and in the world dimension. In particular, M. Ya. Bomba, H. T. Pyrog, S. M. Ryzhuk agriculture with the basics of soil science, agrochemistry and $\operatorname{agroecology}^{19}$; G. I. Demidas, I. D. Primak, V. G. Roshko - rational crop rotation in modern agriculture ${ }^{20}$; V. P. Gudz, I. D. Primak, M. F. Rybak - adaptive systems of farming ${ }^{21}$. In them the history of

15 Orekhivskyi, V. D. (2018) Rozvytok zastosuvannia travosiiannia i travopilnykh sivozmin $v$ orhanichnomu zemlerobstvi URSR u pershii polovyni XX stolittia [Development of the use of herbivores and herbivory crop rotations in the organic agriculture of the USSR in the first half of the XX century]. Istoriia nauky i tekhniky, vol. 8. p. 159. (in Ukrainian).

${ }^{16}$ Kovalenko, N. P. (2012) Istorychni aspekty zarodzhennia i rozvytku naukovykh znan pro syderalni sivozminy [Historical aspects of the origin and development of scientific knowledge about sidereal rotations]. Silskyi hospodar, no. 11-12, pp. 27-33. (in Ukrainian).

${ }^{17}$ Kovalenko, N. P. (2009) Istoriia zarodzhennia i rozvytku naukovykh znan pro travopilni sivozminy [History of the origin and development of scientific knowledge about herbivore rotations]. Istoriia nauky i biohrafistyka (electronic journal), no. 2. Retrieved from: http://inb.dnsgb.com.ua/2009-2/09_kovalenko.pdf (accessed 30 May 2019). (in Ukrainian).

${ }^{18}$ Kovalenko, N. P. (2012) Evoliutsiia naukovykh pohliadiv shchodo alelopatychnoi aktyvnosti silskohospodarskykh kultur u sivozminakh [Evolution of scientific views on allelopathic activity of crops in crop rotation]. Silskohospodarska mikrobiolohiia, vol. 15-16, pp. 161-173. (in Ukrainian).

${ }^{19}$ Bomba, M. Ya., Perih, H. T. \& Ryzhuk, S. M. (2003) Zemlerobstvo z osnovamy gruntoznavstva, ahrokhimii ta ahroekolohii [Agriculture with the basics of soil science, agrochemistry and agroecology]. Kyiv: Urozhai, 400 s. (in Ukrainian).

${ }^{20}$ Prymak, I. D., Roshko, V. I. \& Demydas, I. I. (2003) Ratsionalni sivozminy $v$ suchasnomu zemlerobstvi [Rational crop rotation in modern agriculture]. Bila Tserkva: BDAU, 384 s. (in Ukrainian).

21 Gudz, V. P., Prymak, I. D. \& Rybak, M. F. (2007) Adaptyvni systemy zemlerobstva [Adaptive farming systems]. Kyiv: Tsentr uchbovoi literatury, $336 \mathrm{~s}$. (in Ukrainian). 
formation and development of theoretical-methodological foundations of ecologically safe measures in agriculture on the drained, irrigated and eroded lands is fragmented, but no attention is paid to the researches of Ukrainian scientists ${ }^{22}$.

Valuable scientific publication is V.A. Vergunov, I. D. Primak, V. G. Roshko, which reflects the history of formation and development of scientific bases of agricultural systems, reproduces the evolution of theoretical-methodological aspects of biological of agriculture from ancient times $^{23}$. Scientific works are devoted to the elucidation and solution of problems of ecologization of agriculture in Ukraine: S. V. Begey, I. A. Shuvar ${ }^{24}$, V.P. Gudz, M. F. Rybak, M. M. Tymoshenko ${ }^{25}$, Yu. P. Manko, I. D. Primak, N. M. Reidey ${ }^{26}$. They give a history of the formation and development of the theoretical-methodological foundations of organic farming, but do not trace their relationship with other systems.

Important are the scientific publications dedicated to the development of ecologically sound scientific activities in organic agriculture in Ukraine. In particular, the monographs of O. M. Bunchak, V. M. Sendetsky, I. A. Shuvar ${ }^{27}$, M. K. Linnyk, M. M. Symchuk ${ }^{28}$ explain the history of production and use of organic

22 Orekhivskyi, V. D. (2017) Evoliutsiia naukovykh osnov orhanichnoho zemlerobstva $v$ Ukraini (druha polovyna XIX - pochatok XXI st.): monohrafiia [Evolution of the scientific basis of organic agriculture in Ukraine (the second half of XIX is beginning of XXI of century): monograph]. Vinnytsia: TOV «Nilan-LTD», p. 21. (in Ukrainian).

${ }^{23}$ Prymak, I. D., Verhunov, V. A. \& Roshko, V. H. (2004) Systemy zemlerobstva: istoriia yikh rozvytku $i$ naukovi osnovy [Systems of agriculture: history of their development and scientific basis]. Bila Tserkva: BDAU, 528 s. (in Ukrainian).

${ }^{24}$ Behei, S. V. \& Shuvar, I. A. (2007) Ekolohichne zemlerobstvo [Organic farming]. Lviv: Novyi svit - 2000, 432 s. (in Ukrainian).

${ }^{25}$ Gudz, V.P., Rybak, M.F. \& Tymoshenko, M. M. (2012) Ekolohichni problemy zemlerobstva [Environmental problems of agriculture]. Zhytomyr, $560 \mathrm{~s}$. (in Ukrainian).

26 Prymak, I. D., Manko, Yu. P. \& Ridei, N. M. (2010) Ekolohichni problemy zemlerobstva [Environmental problems of agriculture]. Kyiv: Tsentr uchbovoi literatury, $456 \mathrm{~s}$. (in Ukrainian).

27 Shuvar, I. A., Sendetskyi, V. M. \& Bunchak, O. M. (2015) Vyrobnytstvo ta vykorystannia orhanichnykh dobryv: monohrafiia [Production and use of organic fertilizers: monograph]. Ivano-Frankivsk: Symfoniia forte, 596 s. (in Ukrainian).

28 Linnyk, M. K. \& Symchuk, M. M. (2012) Tekhnolohii i tekhnichni zasoby vyrobnytstva ta vykorystannia orhanichnykh dobryv [Technologies and technical means of production and use of organic fertilizers]. Hlevakha, 248 s. (in Ukrainian). 
fertilizers. The researchers analyzed the formation, development and current state of production and use of traditional organic fertilizers; vermiculture biohumus; microorganisms derived from organic waste from poultry farms, livestock complexes, leather production by aerobic biological fermentation, microbial associations by composting, liquid fertilizer biostimulators by cavitation, straw destruction and sideration. Researchers have developed and implemented in the production of vermiculture technology and biological accelerated fermentation taking into account the climatic and economic conditions of Ukraine in the agricultural enterprises of Vinnitsa, Volyn, Ivano-Frankivsk, Kyiv, Lviv, Khmelnytsky and other regions of Ukraine ${ }^{29}$. Scientific technology of destroying straw and other plant residues by VermistimD destructor in conjunction with sowing of sidereal crops was developed and introduced in agricultural enterprises of the mentioned regions of Ukraine. Researchers have found that expanding the use of ecologically friendly organic fertilizers - straw and green fertilizers - is one of the most important elements of organic farming that increases soil fertility and improves the ecological status of agroecosystems.

The monographs of N. M. Kolisnyk, I. P. Melnyk, I. A. Shuvar ${ }^{30}$, V. O. Andrienko, I. A. Melnyk, M. F. Povkhan ${ }^{31}$ provide important information on the historical aspects of formation and the development of theoretical-methodological foundations for the cultivation and practical application of earthworms in agricultural enterprises of Ukraine. Scientists have clarified the importance of the results of many years of research by Ukrainian and foreign scientists on improving the theoretical-methodological foundations of technologies for the production of biohumus from organic waste by the method of

29 Orekhivskyi, V. D. (2018) Tendentsii rozvytku vermykultury - odnoho $z$ osnovnykh napriamiv orhanichnoho zemlerobstva $v$ Ukraini [Trends in vermiculture one of the main areas of organic farming in Ukraine]. Eminak, no. 21, p. 154. (in Ukrainian).

${ }^{30}$ Melnyk, I. P., Kolisnyk, N. M. \& Shuvar, I. A. (2015) Doshchovi cherviaky: naukovi aspekty vyroshchuvannia $i$ praktychne zastosuvannia: monohrafiia [Earthworms: scientific aspects of growing and practical application: monograph]. Ivano-Frankivsk: Symfoniia forte, $444 \mathrm{~s}$. (in Ukrainian).

31 Povkhan, M. F., Melnyk, I. A. \& Andryenko, V. A. (1994) Vermykultura: proyzvodstvo y yspolzovanye [Vermiculture: production and use]. Kyev: UkrNYYYTEY, 128 s. (in Russia). 
vermiculture, development and use of complex humic preparations from vermiculose compost. The researchers analyzed the development of industrial vermiculture technologies on various types of organic waste and biohumus production: technology of obtaining organicmineral fertilizers based on biohumus, utilization of organic waste with the help of heterotrophic organisms, processing of organic waste by higher edible biobodies ${ }^{32}$. The ways of improving the initial uterine populations and their adaptation to various organic substrates, and obtaining biologically active preparations from the tissues of the vermicultural organism are determined.

Valuable information is contained in scientific publications dedicated to the evolution of scientific-organizational foundations of different soil tillage systems to reproduce soil fertility. In particular, in the monograph V. O. Andrienko, S. S. Antonets, M. K. Shikula the role of perfection of surface ashless cultivation in improvement of soil properties, biochemical mechanism of humus restoration and fertility self-regulation, carbon dioxide assimilation and soil humidity is given. The coefficients of humification of manure and plant residues are specified, the management of soil formation in agrocenoses of Ukraine during the $1970^{\mathrm{s}}-1990^{\mathrm{s}}$ is analyzed in detail ${ }^{33}$. The results of researches of scientists in the long-term multifactorial experiments of the National Agrarian University on improving the efficiency of soil protection technologies in different soil and climatic conditions of Ukraine are presented.

Noteworthy are the publications of V.O. Yeshchenko, Yu. P. Manko, I. D. Primak ${ }^{34}$, F. T. Morgun ${ }^{35}$, devoted to the

32 Orekhivskyi, V. D. (2018) Tendentsii rozvytku vermykultury - odnoho $z$ osnovnykh napriamiv orhanichnoho zemlerobstva v Ukraini [Trends in vermiculture one of the main areas of organic farming in Ukraine]. Eminak, no. 21, p. 153. (in Ukrainian).

33 Shykula, M. K., Antonets, S. S. \& Andriienko, V. O. (1998) Vidtvorennia rodiuchosti gruntiv u gruntozakhysnomu zemlerobstvi: naukova monohrafiia [Soil fertility reproduction in soil protection agriculture: scientific monograph]. Kyiv: Oranta, 680 s. (in Ukrainian).

${ }^{34}$ Prymak, I. D., Yeshchenko, V. O. \& Manko, Yu. P. (2007) Resursozberihaiuchi tekhnolohii mekhanichnoho obrobitku gruntu $v$ suchasnomu zemlerobstvi Ukrainy [Resource-saving technologies of mechanical tillage in modern agriculture of Ukraine]. Kyiv : KVITs, 272 s. (in Ukrainian). 
elucidation of the process of improving the theoretical-methodological foundations of resource-saving technologies of soil cultivation in soil protection agriculture of Ukraine. According to the results of many years of research, the systematic application on the slopes of soil protective technologies of cultivation of crops contributed to the formation of agrophysical indicators of the treated soil layer, which reduced the manifestations of erosion: increased water permeability, structural and water resistance of aggregates ${ }^{36}$.

In the monograph by M. P. Kosolap, O. P. Krotinov, the history of the development of the scientific bases of agricultural systems is analyzed, in particular, the features of the propagation of technologies of cultivation of crops for the systems of agriculture "No-till", N. P. Kovalenko's publications, the evolution of the use of soil tillage tools has been elucidated since ancient times ${ }^{38}$. The researcher established the basic laws and tendencies of the use of the soil tillage system by the method of T.S. Maltsev in the Ukraine in the $1950^{\mathrm{s}}$. Defined cultivation of soil in crops of different crops of the Steppe, Forest-steppe and Polesie of the Ukraine ${ }^{39}$.

The history of the development of the scientific foundations of biological measures of plant protection against diseases and pests is covered in the publications of V.P. Vasylyev, M. P. Lisovyi ${ }^{40}$,

35 Morhun, F. T. (2008). Vybir Ukrainy - poriatunok pryrody i sela [Ukraine's choice is to save nature and the countryside]. Poltava: Dyvosvit. 236 s. (in Ukrainian).

${ }^{36}$ Orekhivskyi, V. D. (2017) Evoliutsiia naukovykh osnov zastosuvannia obrobitku gruntu v orhanichnomu zemlerobstvi Ukrainy (druha polovyna XIX - pochatok XXI st.) [Evolution of scientific bases of application of soil cultivation in organic agriculture of Ukraine (second half of XIX - beginning of XXI century)]. Visnyk ahrarnoi istorii, vol. 19-20. p. 221. (in Ukrainian).

37 Kosolap, M. P. \& Krotinov, O. P. (2011) Systema zemlerobstva No-Till [The system farming No-Till]. Kyiv: Lohos, 352 s. (in Ukrainian).

38 Kovalenko, N. P. (2016) Evoliutsiia vykorystannia znariad obrobitku gruntu u vitchyznianomu zemlerobstvi [Evolution of the use of soil tillage tools in domestic agriculture]. History of science and technique, vol. 8, pp. 129-139. (in Ukrainian).

${ }^{39}$ Kovalenko, N. P. (2018) Evoliutsiia zastosuvannia systemy obrobitku gruntu za metodom T. S. Maltseva v URSR u 1954-1955 rokakh [Evolution of the application of the soil tillage system by the method of T. S. Maltsev in the Ukraine in 1954-1955]. Istoriia nauky i tekhniky, vol. 11. pp. 175-186. (in Ukrainian).

${ }^{40}$ Vasylev, V. P. \& Lesovoi, M. P. (1996) Ystoryia zashchyty rastenyi ot vredytelei $y$ boleznei $v$ Ukrayne [The history of plant protection from pests and diseases in Ukraine]. Kyev: Ahrarna nauka, 132 s. (in Russia). 
V. P. Konverska, O. M. Tkalenko, V. P. Fedorenko ${ }^{41}$. The ecological basis for the reduction of agrophytocenosis weediness is in I. A. Shuvar's monograph ${ }^{42}$. These publications provide a history of developing the scientific-theoretical foundations of ecologically safe control of agrophytocenosis weeds and the reduction of disease and pests. Researchers have discovered the wide organizational possibilities of using agrotechnical and biological methods to attenuate the phytotoxic action of residues of agrochemicals, depending on soil and climatic conditions, biochemical characteristics of plants and physicochemical properties of herbicides.

Of great importance are the scientific publications dedicated to the evolution of the scientific and organizational foundations of soil erosion protection measures. In the monograph of M. D. Voloshchuk, N. I. Petrenko, S. V. Yatsenko the classical essence of soil erosion is revealed on the basis of historical and recent sources and the consequences of influence on the earth's surface of water, wind and anthropogenic factors are determined ${ }^{43}$. Scientists have substantiated the need to further improve the theoretical-methodological foundations of erosion science in order to accelerate the introduction of soil protection measures in the production. The history of formation and development of scientific centers of erosion science in different soil and climatic conditions of Ukraine is given; the current state and prospects of the development of theoretical-methodological foundations of soil protection against erosion are highlighted ${ }^{44}$.

${ }^{41}$ Fedorenko, V. P., Tkalenko, A. N. \& Konverskaia, V. P. (2010) Dostyzhenyia y perspektyvy razvytyia byolohycheskoho metoda zashchyty rastenyi $v$ Ukrayne [Achievements and development prospects of the biological method of plant protection in Ukraine]. Zashchyta y karantyn rastenyi, no. 4, pp. 12-15. (in Russia).

42 Shuvar, I. A. (2008) Ekolohichni osnovy znyzhennia zaburianenosti ahrofitotsenoziv [Environmental basics of agrophytocenosis weed reduction]. Lviv: Novyi Svit - 2000, 496 s. (in Ukrainian).

43 Voloshchuk, M. D., Petrenko, N. I. \& Yatsenko, S. V. (2014) Eroziia gruntiv Ukrainy: evoliutsiia teorii i praktyky: monohrafiia [Soil erosion of Ukraine: evolution of theory and practice: monograph]. Kyiv: TOV «Nilan-LTD», $326 \mathrm{~s}$. (in Ukrainian).

44 Orekhivskyi, V. D. (2017) Evoliutsiia naukovykh osnov orhanichnoho zemlerobstva $v$ Ukraini (druha polovyna XIX - pochatok XXI st.): monohrafiia [Evolution of the scientific basis of organic agriculture in Ukraine (the second half of XIX is beginning of XXI of century): monograph]. Vinnytsia: TOV «Nilan-LTD», p. 133. (in Ukrainian). 
In the publication of N. P. Kovalenko, the evolution of the development of economic-mathematical methods for the optimization of soil-protective crop rotations in the second half of the $20^{\text {th }}-$ the beginning of the $21^{\text {st }}$ century is widely analyzed ${ }^{45}$. The researcher found that the optimization of soil protection crop rotation was based on the rational use of land potential of the state and restoration of ecological equilibrium of agricultural landscapes, organization of land use and solving the problem of environmental protection ${ }^{46}$. It carried out the classification and generalization of environmental criteria, which improved and expanded the dimension of economicmathematical models.

Of great importance is the monograph of the team of scientists of the National Scientific Center "Institute of Agriculture of the NAAS", edited by Ya. M. Hadzalo, which is devoted to a fundamental study of the history of the development of theoretical-methodological foundations of organic production in various soil and climatic conditions of Ukraine ${ }^{47}$. In particular, scientists have determined the prerequisites for the emergence of organic movement, the soil and climatic signs of organic agriculture in Ukraine, the features of production, regulatory and legal support, the formation and functioning of the organic produce market in Ukraine ${ }^{48}$.

45 Kovalenko, N. P. (2011) Istoriia optymizatsii gruntozakhysnykh sivozmin na osnovi ekonomiko-matematychnoho modeliuvannia druhoi polovyny XX - XXI stolittia [History of optimization of soil-protective crop rotations on the basis of economic and mathematical modeling of the second half of the XX - XXI centuries]. Istoriia nauky $i$ biohrafistyka (electronic journal), no. 1. Retrieved from: http://www.inb.dnsgb.com.ua/ 2011-1/11_kovalenko.pdf (accessed 30 May 2019). (in Ukrainian).

46 Orekhivskyi, V. D. (2017) Evoliutsiia naukovykh osnov orhanichnoho zemlerobstva $v$ Ukraini (druha polovyna XIX - pochatok XXI st.): monohrafiia [Evolution of the scientific basis of organic agriculture in Ukraine (the second half of XIX is beginning of XXI of century): monograph]. Vinnytsia: TOV «Nilan-LTD», p. 146. (in Ukrainian).

47 Hadzalo, Ya. M. (ed.) (2016) Naukovi osnovy vyrobnytstva orhanichnoi produktsii v Ukraini: monohrafiia [Scientific bases of organic production in Ukraine: monograph]. Kyiv: Ahrarna nauka, 592 s. (in Ukrainian).

${ }^{48}$ Orekhivskyi, V. D. (2017) Evoliutsiia naukovykh osnov orhanichnoho zemlerobstva $v$ Ukraini (druha polovyna XIX - pochatok XXI st.): monohrafiia [Evolution of the scientific basis of organic agriculture in Ukraine (the second half of XIX 


\section{Development of scientific-practical foundations of organic farming in Ukraine in epy historiography of the independence period}

One of the first fundamental works of economic direction to improve the process of organic production was the monograph M. M. Fedorov, O. V. Khodakivska， S. G. Korchinska ${ }^{49}$. The researchers analyzed the history of the development of scientific-practical foundations of world and domestic production of organic products, the formation of regulatory framework, features of market development, standardization and certification of organic products. Scientists have conditionally identified three main stages of the transition of the Private enterprise "Agroecology" of Poltava region to organic production. The first dates back to 1976, when the collective farm named Ordzhonikidze became the basic farm for the production testing of the use of soil-protective agriculture ${ }^{50}$. The second stage began in 1979, a feature of which was the introduction into the management of soil biological technologies, the basis of which was the complete rejection of pesticides in the fields. The third stage, characterized as the development of organic farming, began in 1986, when synthetic mineral fertilizers were replaced on the farm by the use of organic fertilizers and siderates.

The monograph of V. V. Pindus, V. V. Rekunenko, P. A. Stetsyshyn describes the evolution of scientific-practical foundations of organic production, the introduction of innovative technologies for growing and harvesting field, vegetable and fruit crops in organic agriculture $^{51}$. Scientists have scientifically substantiated the

is beginning of XXI of century): monograph]. Vinnytsia: TOV «Nilan-LTD», p. 215. (in Ukrainian).

49 Fedorov, M. M., Khodakivska, O. V. \& Korchynska, S. H. (2011) Rozvytok orhanichnoho vyrobnytstva [Development of organic production]. Kyiv: NNTs IAE, 146 s. (in Ukrainian).

50 Orekhivskyi, V. D. (2018) Evoliutsiia vprovadzhennia systemy orhanichnoho zemlerobstva v Pryvatnomu Pidpryiemstvi «Ahroekolohiia» $u$ druhii polovyni XX - na pochatku XXI stolit [Evolution of the organic farming system implementation in PE «Agroecology» in the second half of XX - at the beginning XXI of centuries]. Hileia, vol. 130, p. 116. (in Ukrainian).

51 Stetsyshyn, P. O., Pyndus, V. V. \& Rekunenko, V. V. (2011) Osnovy orhanichnoho vyrobnytstva [Fundamentals of organic production]. Vinnytsia: Nova knyha, 552 s. (in Ukrainian). 
development of organic, biodynamic systems of agriculture and technologies of effective microorganisms, advanced methods of using microbiological preparations for the control of pests and diseases of crops, as well as a system of machines for organic production. Researchers have analyzed the development of practical production of organic crop and livestock production at enterprises in different soil and climatic conditions of Ukraine in the early $21^{\text {st }}$ century.

Further development of research was covered in the monograph T. G. Dudar, O. T. Dudar, which clarified the scientific-organizational principles of the formation and development of organic farming. Systematic analysis and evaluation of the practical management of organic farming in agrarian enterprises, provided conceptual organizational-economic principles of the strategy of formation and development of organic production in the context of ecologization the agrosphere ${ }^{52}$. The researchers found that during the 1990-2000', Ukraine, with significant potential for organic production, export, consumption on the domestic market, achieved certain results in developing its own organic production. Scientists have identified significant growth in Ukraine at the beginning of the $21^{\text {th }}$ century certified organic farms for organic production ${ }^{53}$. They determined that, given the significant regional features of the agrarian sector of Ukraine, certified organic farms that produced organic crop products, overwhelmingly specialized in growing winter wheat, spring barley, rye, oats, buckwheat, sunflower, soybean, soybean, supplementary crops.

From the standpoint of the systematic approach in the T. A. Chaika monograph, the scientific and organizational aspects of organic production as a strategic direction for the development of the agrarian sector of the Ukraine economy have been investigated ${ }^{54}$. In the opinion

52 Dudar, T. H. \& Dudar, O. T. (2012) Stratehiia formuvannia systemy orhanichnoho ahrarnoho vyrobnytstva: monohrafiia [The strategy of forming a system of organic agricultural production: monograph]. Ternopil: Aston, 292 s. (in Ukrainian).

53 Orekhivskyi, V. D. (2017) Evoliutsiia naukovykh osnov orhanichnoho zemlerobstva $v$ Ukraini (druha polovyna XIX - pochatok XXI st.): monohrafiia [Evolution of the scientific basis of organic agriculture in Ukraine (the second half of XIX is beginning of XXI of century): monograph]. Vinnytsia: TOV «Nilan-LTD», p. 27. (in Ukrainian).

${ }^{54}$ Chaika, T. O. (2013) Rozvytok vyrobnytstva orhanichnoi produktsii v ahrarnomu sektori ekonomiky Ukrainy: monohrafiia [Development of organic production in the agricultural sector of the Ukrainian economy: monograph]. Donetsk: Noulidzh, 320 s. (in Ukrainian). 
of the researcher it was important to find out the essence of the formation and development of organic production in agricultural enterprises of Ukraine with the need to evaluate their effectiveness. The scientist analyzed the development of scientific-practical bases of application of organic technologies in certified organic enterprises of Ukraine at the beginning of the $21^{\text {st }}$ century. In particular, the company "EthnoProduct" of Chernihiv region, which produced organic products, focusing on domestic and foreign markets. It has been found that over the years of its development, the enterprise has become one of the powerful producers of organic cereals, legumes, oil and vegetables, meat, milk and honey in Ukraine ${ }^{55}$. The scientist found that organic products on the farm were grown without genetically modified organisms, hormones, growth promoters, pesticides and other agrochemicals in environmentally safe conditions. The activity of company "Living Planet Potutory" of Ternopil region was analyzed, which used biodynamic preparations, which was based on expanding the market of organic products and its assortment due to grain processing into cereals and flour. Efficiency of company "Old Porytsk" of the Volyn region, which due to introduction of modern technologies and strict control at all stages of production of organic production, has reached high indicators of quality of production. The activity of company "Organic Original" of Kyiv region, which specialized in the production of cold pressed sunflower oil, organic cereals, flour, honey, was determined effectively. The production of the company had a European organic certificate and is marked with the official logo of the European Union organics - "Eurolyst".

In the monograph by O. V. Khodakivska it is noted that organic agriculture is a component of greening of agrarian production ${ }^{56}$. The researcher reflects foreign experience of practical management of organic agriculture and features of its regulation, shows the

55 Orekhivskyi, V. D. (2018) Osoblyvosti rozvytku ahrarnykh pidpryiemstv z vyrobnytstva orhanichnoi produktsii v Ukraini (1990-ti - 2000-ni roky) [Features of development of agricultural enterprises for organic production in Ukraine $\left(1990^{\mathrm{S}}\right.$ $\left.2000^{\mathrm{S}}\right)$ ]. Hileia, vol. 133, p. 68. (in Ukrainian).

${ }^{56}$ Khodakivska, O. V. (2015) Ekolohizatsiia ahrarnoho vyrobnytstva: monohrafiia [Ecologization of agricultural production: monograph]. Kyiv: NNTs IAE, p. 159. (in Ukrainian). 
development of organic production in certified farms in Ukraine. The efficiency of scientific and practical bases of organic production in the Private enterprise "Agroecology" of Poltava region is analyzed ${ }^{57}$. Improvement of the efficiency of scientific technologies of organic production in the Private enterprise "Agroecology" due to their economic feasibility, ecological safety, energy and resource conservation, as well as social orientation is established.

Extensive information is contained in scientific publications on the development of organic production enterprises in Ukraine. In particular, the monographs of S. S. Antonets, A. S. Antonets, V. M. Pisarenko, P. V. Pisarenko about the experience of practical management ${ }^{58}$ and improvement of the system of organic farming in the Private enterprise "Agroecology" of Poltava region". Researchers have paid great attention to the history of the development of the use of environmentally friendly measures in organic farming, which were introduced in the economy during 1976-2017. The application of organic fertilizers, the cultivation of sidereal, post-harvest and postharvest crops, the use of environmentally friendly agrotechnical measures and microbiological preparations ${ }^{60}$. To compensate for the nutrients in the farm used organic fertilizers: manure, siderates, postharvest residues, which fully met the requirements of organic farming. Their introduction ensured the preservation and extended reproduction

57 Orekhivskyi, V. D. (2017) Evoliutsiia naukovykh osnov orhanichnoho zemlerobstva $v$ Ukraini (druha polovyna XIX - pochatok XXI st.): monohrafiia [Evolution of the scientific basis of organic agriculture in Ukraine (the second half of XIX is beginning of XXI of century): monograph]. Vinnytsia: TOV «Nilan-LTD», p. 336. (in Ukrainian).

58 Antonets, S. S., Antonets, A. S. \& Pysarenko, V. M. (2010) Orhanichne zemlerobstvo: z dosvidu PP «Ahroekolohiia» Shyshatskoho raionu Poltavskoi oblasti [Organic farming: from the experience of the PE «Agroecology» of Shishatsky district of Poltava region]. Poltava: RVV PDAA, 200 s. (in Ukrainian).

59 Pysarenko, V. M., Antonets, A. S. \& Pysarenko, P. V. (2017) Systema orhanichnoho zemlerobstva ahroekoloha Semena Antontsia [Organic farming system of agroecologist Semen Antonets]. Poltava: FOP Myron, I. A. 124 s. (in Ukrainian).

${ }^{60}$ Orekhivskyi, V. D. (2018) Evoliutsiia vprovadzhennia systemy orhanichnoho zemlerobstva v Pryvatnomu Pidpryiemstvi «Ahroekolohiia» u druhii polovyni XX - na pochatku XXI stolit [Evolution of the organic farming system implementation in PE «Agroecology» in the second half of XX - at the beginning XXI of centuries]. Hileia, vol. 130, p. 115. (in Ukrainian). 
of soil fertility and the production of ecologically friendly crop and livestock products.

Important is the information of O. M. Yushchenko on the development of organic production in the Zhytomyr region ${ }^{61}$. It analyzed one of the largest organic farms in Ukraine - the Private Enterprise "Galeks-Agro", which implemented a model of a fullfledged ecological system, which combined organic crop production and organic animal husbandry. Important is the information on obtaining the status of organic in 2009 with the certification of organic production $^{62}$.

In the scientific publication V. M. Pisarenko, P. V. Pisarenko, S. V. Ponomarenko the development of ecologically safe production for practical use in the private sector of Ukraine and measures to reduce the content of harmful substances in food at the beginning of the $21^{\text {st }}$ century are analyzed ${ }^{63}$. Researchers have characterized the features of cultivation technologies of field and vegetable crops in open and closed soil, the development of the use of plant infusions and decoctions for the control of leaf pests and diseases, as well as ecologically safe substances for plant protection ${ }^{64}$.

61 Yushchenko, O. M. (2017) Rozvytok orhanichnoho vyrobnytstva na Zhytomyrshchyni: dosvid PP «Haleks-Ahro» [Development of organic production in Zhytomyr region: experience of PE «Galex-Agro»]. Retrieved from: http://www.znau.edu.ua/media/nauka_innovation/organic/Organic_20132.pdf (accessed 30 May 2019). (in Ukrainian).

62 Orekhivskyi, V. D. (2018) Osoblyvosti rozvytku ahrarnykh pidpryiemstv z vyrobnytstva orhanichnoi produktsii v Ukraini (1990-ti - 2000-ni roky) [Features of development of agricultural enterprises for organic production in Ukraine $\left(1990^{\mathrm{s}}\right.$ $2000^{\mathrm{s}}$ )]. Hileia, vol. 133, p. 69. (in Ukrainian).

${ }^{63}$ Pysarenko, V. M., Pysarenko, P. V. \& Ponomarenko, S. V. (2017) Orhanichne zemlerobstvo dlya pryvatnoho sektora [Organic agriculture is for a private sector]. Poltava: FOP Myron, I. A., 140 s. (in Ukrainian).

${ }^{64}$ Orekhivskyi, V. D. (2018) Evoliutsiia vprovadzhennia systemy orhanichnoho zemlerobstva v Pryvatnomu Pidpryiemstvi «Ahroekolohiia» $u$ druhii polovyni XX - na pochatku XXI stolit [Evolution of the organic farming system implementation in PE «Agroecology» in the second half of XX - at the beginning XXI of centuries]. Hileia, vol. 130, p. 117. (in Ukrainian). 


\section{CONCLUSION}

It can be concluded that the historiography on the evolution of the scientific-organizational foundations of organic farming in the period of Ukraine's independence is multifaceted both in terms of the generalizations presented and the level of study of the problems considered by scientists. In the historical scientific works the formation and development of separate scientific directions of organic farming in different soil and climatic conditions of Ukraine are defined. In particular, the application of theoretical-methodological aspects regarding scientifically grounded structure of sown areas and specialized crop rotations with perennial legumes, rational cultivation of soil, application of organic fertilizers, cultivation of sidereal crops, use of biohumus, mulching and microbiological preparations.

In the historiography of the period of independence of Ukraine the attention is paid to the history of development of scientific-practical bases of production of organic products at the enterprises, formation of the legal base, features of market development, standardization and certification of organic products. However, it was important not only their comprehensive and systematic research, but also the need to introduce into the circulation of unknown and unknown documentary sources, which ensured the restoration of a holistic process of evolution of scientific-organizational foundations of organic agriculture in independent Ukraine.

\section{SUMMARY}

The article provides an overview and analysis of basic research on the history of the formation and development of scientificorganizational foundations of organic agriculture in different soil and climatic conditions of independent Ukraine. By combining the principles of historicism and objectivity with the use of general scientific and special-historical methods: problem-chronological, comparative-historical, retrospective, source studies, a comprehensive scientific-historical analysis of the comprehensive and objective coverage of the development of scientific-organizational foundations of organic agriculture in independent Ukraine with the application of ecologically friendly measures and rational technologies of cultivation of crops. 
It is determined that the historiography of the period of independence of Ukraine on the evolution of scientific-organizational foundations of organic farming is multifaceted both in terms of the presented generalizations and in the level of study of problems considered by scientists. The value of historical works that reproduce the history of science and research in the field of organic farming in Ukraine has been clarified. In particular, the evolution of particular scientific directions, theories, concepts and scientific technologies in organic farming. Contribution to the development of scientific technologies of organic farming of higher education institutions, research institutions and research teams; the evolution of the scientific foundations of organic farming in the context of the activities of wellknown agrarian scientists; development of practical introduction of organic farming in organic production enterprises and the like.

The introduction into the scientific circulation of little-known and unknown documentary sources ensured the restoration of the holistic state of evolution of the scientific-organizational foundations of organic farming in independent Ukraine. It has been found that studies of Ukrainian historians of agrarian science have contributed to the objective and holistic reproduction of individual processes and patterns of evolution of the theoretical-methodological and scientific-practical foundations of organic agriculture, ensuring the application of historical methods and approaches.

\section{REFERENCES}

1. Antonets, S. S., Antonets, A. S. \& Pysarenko, V. M. (2010) Orhanichne zemlerobstvo: $z$ dosvidu PP "Ahroekolohiia" Shyshatskoho raionu Poltavskoi oblasti [Organic farming: from the experience of the PE "Agroecology" of Shishatsky district of Poltava region]. Poltava: RVV PDAA, 200 s. (in Ukrainian).

2. Behei, S. V. \& Shuvar, I. A. (2007) Ekolohichne zemlerobstvo [Organic farming]. Lviv: Novyi svit - 2000, 432 s. (in Ukrainian).

3. Boiko, P. I. \& Kovalenko, N. P. (2004) Systemy zemlerobstva ta sivozminy: istoriia, suchasnyi stan i perspektyvy rozvytku [Systems of agriculture and crop rotation: history, current state and prospects for development]. Visnyk Poltavskoi derzhavnoi ahrarnoi akademii, vol. 3, pp. 21-26. (in Ukrainian). 
4. Boiko, P. I. \& Kovalenko, N. P. (2005) Istorychni $i$ suchasni dosiahnennia $u$ vyvchenni ta vprovadzhenni system zemlerobstva $i$ sivozmin [Historical and contemporary achievements in the study and implementation of farming systems and crop rotations]. Ahronom, no. 3, pp. 78-81. (in Ukrainian).

5. Boiko, P. I. \& Kovalenko, N. P. (2008) Pary v proshlom y sovremennom zemledelyy [Pairs in past and present agriculture]. Ahrovisnyk Ukraina. no. 2. pp. 14-17. (in Russia).

6. Bomba, M. Ya., Perih, H. T. \& Ryzhuk, S. M. (2003) Zemlerobstvo $z$ osnovamy gruntoznavstva, ahrokhimii ta ahroekolohii [Agriculture with the basics of soil science, agrochemistry and agroecology]. Kyiv: Urozhai, 400 s. (in Ukrainian).

7. Chaika, T. O. (2013) Rozvytok vyrobnytstva orhanichnoi produktsii $v$ ahrarnomu sektori ekonomiky Ukrainy: monohrafiia [Development of organic production in the agricultural sector of the Ukrainian economy: monograph]. Donetsk: Noulidzh, 320 s. (in Ukrainian).

8. Dudar, T. H. \& Dudar, O. T. (2012) Stratehiia formuvannia systemy orhanichnoho ahrarnoho vyrobnytstva: monohrafiia [The strategy of forming a system of organic agricultural production: monograph]. Ternopil: Aston, 292 s. (in Ukrainian).

9. Fedorenko, V. P., Tkalenko, A. N. \& Konverskaia, V. P. (2010) Dostyzhenyia y perspektyvy razvytyia byolohycheskoho metoda zashchyty rastenyi $v$ Ukrayne [Achievements and development prospects of the biological method of plant protection in Ukraine]. Zashchyta y karantyn rastenyi, no. 4, pp. 12-15. (in Russia).

10. Fedorov, M. M., Khodakivska, O. V. \& Korchynska, S. H. (2011) Rozvytok orhanichnoho vyrobnytstva [Development of organic production]. Kyiv: NNTs IAE, 146 s. (in Ukrainian).

11. Gudz, V. P., Prymak, I. D. \& Rybak, M. F. (2007) Adaptyvni systemy zemlerobstva [Adaptive farming systems]. Kyiv: Tsentr uchbovoi literatury, $336 \mathrm{~s}$. (in Ukrainian).

12. Gudz, V. P., Rybak, M. F. \& Tymoshenko, M. M. (2012) Ekolohichni problemy zemlerobstva [Environmental problems of agriculture]. Zhytomyr, 560 s. (in Ukrainian).

13. Hadzalo, Ya. M. (ed.) (2016) Naukovi osnovy vyrobnytstva orhanichnoi produktsii $v$ Ukraini: monohrafiia [Scientific bases of 
organic production in Ukraine: monograph]. Kyiv: Ahrarna nauka, 592 s. (in Ukrainian).

14. Khodakivska, O. V. (2015) Ekolohizatsiia ahrarnoho vyrobnytstva: monohrafiia [Ecologization of agricultural production: monograph]. Kyiv: NNTs IAE, 350 s. (in Ukrainian).

15. Kovalenko, N. P. (2009) Istoriia zarodzhennia $i$ rozvytku naukovykh znan pro travopilni sivozminy [History of the origin and development of scientific knowledge about herbivore rotations]. Istoriia nauky $i$ biohrafistyka (electronic journal), no. 2. Retrieved from: http://inb.dnsgb.com.ua/2009-2/09_kovalenko.pdf (accessed 30 May 2019). (in Ukrainian).

16. Kovalenko, N. P. (2011) Istoriia optymizatsii gruntozakhysnykh sivozmin na osnovi ekonomiko-matematychnoho modeliuvannia druhoi polovyny XX - XXI stolittia [History of optimization of soil-protective crop rotations on the basis of economic and mathematical modeling of the second half of the XX XXI centuries]. Istoriia nauky $i$ biohrafistyka (electronic journal), no. 1. Retrieved from: http://www.inb.dnsgb.com.ua/20111/11_kovalenko.pdf (accessed 30 May 2019). (in Ukrainian).

17. Kovalenko, N. P. (2012) Ekolohichno zbalansovani sivozminy $v$ systemi alternatyvnoho zemlerobstva: istorychni aspekty [Ecologically balanced crop rotation in the system of alternative agriculture: historical aspects]. Ahroekolohichnyi zhurnal, no. 4, pp. 95-99. (in Ukrainian).

18. Kovalenko, N. P. (2012) Evoliutsiia naukovykh pohliadiv shchodo alelopatychnoi aktyvnosti silskohospodarskykh kultur $u$ sivozminakh [Evolution of scientific views on allelopathic activity of crops in crop rotation]. Silskohospodarska mikrobiolohiia, vol. 15-16, pp. 161-173. (in Ukrainian).

19. Kovalenko, N. P. (2012) Istorychni aspekty zarodzhennia $i$ rozvytku naukovykh znan pro syderalni sivozminy [Historical aspects of the origin and development of scientific knowledge about sidereal rotations]. Silskyi hospodar, no. 11-12, pp. 27-33. (in Ukrainian).

20. Kovalenko, N. P. (2014) Stanovlennia ta rozvytok naukovoorhanizatsiinykh osnov zastosuvannia vitchyznianykh sivozmin $u$ systemakh zemlerobstva (druha polovyna XIX - pochatok XXI st.): monohrafiia [Becoming and development of scientificallyorganizational bases of application of home crop rotations in the 
systems of agriculture (the second half of XIX is beginning of XXI of century): monograph]. Kyiv: TOV "Nilan-LTD”, 490 s. (in Ukrainian).

21. Kovalenko, N. P. (2016) Evoliutsiia vykorystannia znariad obrobitku gruntu $u$ vitchyznianomu zemlerobstvi [Evolution of the use of soil tillage tools in domestic agriculture]. History of science and technique, vol. 8, pp. 129-139. (in Ukrainian).

22. Kovalenko, N. P. (2017) Zarodzhennia naukovykh osnov orhanichnoho zemlerobstva $v$ Ukraini u XVIII - pershii polovyni XIX stolit [The emergence of the scientific foundations of organic farming in Ukraine in the XVIII - first half of the XIX centuries]. Visnyk ahrarnoi istorii, vol. 19-20, pp. 200-216. (in Ukrainian).

23. Kovalenko, N. P. (2017) Evoliutsiia naukovykh osnov orhanichnoho zemlerobstva $v$ Ukraini $u$ druhii polovyni XIX - na pochatku XXI stolit [The evolution of the scientific foundations of organic farming in Ukraine in the second half of the XIX - at the beginning XXI centuries]. Visnyk ahrarnoi istorii, vol.21-22, pp. 258-268. (in Ukrainian).

24. Kovalenko, N. P. (2018) Evoliutsiia zastosuvannia systemy obrobitku gruntu za metodom T. S. Maltseva v URSR u 1954-1955 rokakh [Evolution of the application of the soil tillage system by the method of T. S. Maltsev in the Ukraine in 1954-1955]. Istoriia nauky $i$ tekhniky, vol. 11. pp. 175-186. (in Ukrainian).

25. Kosolap, M. P. \& Krotinov, O. P. (2011) Systema zemlerobstva No-Till [The system farming No-Till]. Kyiv: Lohos, 352 s. (in Ukrainian).

26. Linnyk, M. K. \& Symchuk, M. M. (2012) Tekhnolohii $i$ tekhnichni zasoby vyrobnytstva ta vykorystannia orhanichnykh dobryv [Technologies and technical means of production and use of organic fertilizers]. Hlevakha, 248 s. (in Ukrainian).

27. Melnyk, I. P., Kolisnyk, N. M. \& Shuvar, I. A. (2015) Doshchovi cherviaky: naukovi aspekty vyroshchuvannia $i$ praktychne zastosuvannia: monohrafiia [Earthworms: scientific aspects of growing and practical application: monograph]. Ivano-Frankivsk: Symfoniia forte, $444 \mathrm{~s}$. (in Ukrainian).

28. Morhun, F. T. (2008). Vybir Ukrainy - poriatunok pryrody $i$ sela [Ukraine's choice is to save nature and the countryside]. Poltava: Dyvosvit. 236 s. (in Ukrainian). 
29. Orekhivskyi, V. D. (2017) Evoliutsiia naukovykh osnov orhanichnoho zemlerobstva v Ukraini (druha polovyna XIX - pochatok XXI st.): monohrafiia [Evolution of the scientific basis of organic agriculture in Ukraine (the second half of XIX is beginning of XXI of century): monograph]. Vinnytsia: TOV "Nilan-LTD", $550 \mathrm{~s}$. (in Ukrainian).

30. Orekhivskyi, V. D. (2017) Evoliutsiia naukovykh osnov zastosuvannia obrobitku gruntu v orhanichnomu zemlerobstvi Ukrainy (druha polovyna XIX - pochatok XXI st.) [Evolution of scientific bases of application of soil cultivation in organic agriculture of Ukraine (second half of XIX - beginning of XXI century)]. Visnyk ahrarnoi istorii, vol. 19-20. pp. 216-222. (in Ukrainian).

31. Orekhivskyi, V. D. (2018) Rozvytok zastosuvannia travosiiannia $i$ travopilnykh sivozmin $v$ orhanichnomu zemlerobstvi URSR $u$ pershii polovyni XX stolittia [Development of the use of herbivores and herbivory crop rotations in the organic agriculture of the USSR in the first half of the XX century]. Istoriia nauky i tekhniky, vol. 8. pp. 158-168. (in Ukrainian).

32. Orekhivskyi, V. D. (2018) Tendentsii rozvytku vermykultury odnoho z osnovnykh napriamiv orhanichnoho zemlerobstva $v$ Ukraini [Trends in vermiculture - one of the main areas of organic farming in Ukraine]. Eminak, no. 21, pp. 150-155. (in Ukrainian).

33. Orekhivskyi, V. D. (2018) Evoliutsiia vprovadzhennia systemy orhanichnoho zemlerobstva $v \quad$ Pryvatnomu Pidpryiemstvi "Ahroekolohiia" u druhii polovyni XX - na pochatku XXI stolit [Evolution of the organic farming system implementation in PE "Agroecology" in the second half of XX - at the beginning XXI of centuries]. Hileia, vol. 130, pp. 115-117. (in Ukrainian).

34. Orekhivskyi, V. D. (2018) Osoblyvosti rozvytku ahrarnykh pidpryiemstv $z$ vyrobnytstva orhanichnoi produktsii $v$ Ukraini (1990-ti - 2000-ni roky) [Features of development of agricultural enterprises for organic production in Ukraine $\left(1990^{\mathrm{s}}-2000^{\mathrm{s}}\right)$ ]. Hileia, vol. 133, pp. 67-69. (in Ukrainian).

35. Pysarenko, V. M., Antonets, A. S. \& Pysarenko, P. V. (2017) Systema orhanichnoho zemlerobstva ahroekoloha Semena Antontsia [Organic farming system of agroecologist Semen Antonets]. Poltava: FOP Myron, I. A. 124 s. (in Ukrainian). 
36. Pysarenko, V. M., Pysarenko, P. V. \& Ponomarenko, S. V. (2017) Orhanichne zemlerobstvo dlya pryvatnoho sektora [Organic agriculture is for a private sector]. Poltava: FOP Myron, I. A., $140 \mathrm{s.}$ (in Ukrainian).

37. Povkhan, M. F., Melnyk, I. A. \& Andryenko, V. A. (1994) Vermykultura: proyzvodstvo y yspolzovanye [Vermiculture: production and use]. Kyev: UkrNYYYTEY, 128 s. (in Russia).

38. Prymak, I. D., Roshko, V. I. \& Demydas, I. I. (2003) Ratsionalni sivozminy $v$ suchasnomu zemlerobstvi [Rational crop rotation in modern agriculture]. Bila Tserkva: BDAU, $384 \mathrm{~s}$. (in Ukrainian).

39. Prymak, I. D., Verhunov, V. A. \& Roshko, V. H. (2004) Systemy zemlerobstva: istoriia yikh rozvytku i naukovi osnovy [Systems of agriculture: history of their development and scientific basis]. Bila Tserkva: BDAU, 528 s. (in Ukrainian).

40. Prymak, I. D., Yeshchenko, V. O. \& Manko, Yu. P. (2007) Resursozberihaiuchi tekhnolohii mekhanichnoho obrobitku gruntu $v$ suchasnomu zemlerobstvi Ukrainy [Resource-saving technologies of mechanical tillage in modern agriculture of Ukraine]. Kyiv : KVITs, 272 s. (in Ukrainian).

41. Prymak, I. D., Manko, Yu. P. \& Ridei, N. M. (2010) Ekolohichni problemy zemlerobstva [Environmental problems of agriculture]. Kyiv: Tsentr uchbovoi literatury, 456 s. (in Ukrainian).

42. Shykula, M. K., Antonets, S. S. \& Andriienko, V. O. (1998) Vidtvorennia rodiuchosti gruntiv u gruntozakhysnomu zemlerobstvi: naukova monohrafiia [Soil fertility reproduction in soil protection agriculture: scientific monograph]. Kyiv: Oranta, 680 s. (in Ukrainian).

43. Shuvar, I. A. (2008) Ekolohichni osnovy znyzhennia zaburianenosti ahrofitotsenoziv [Environmental basics of agrophytocenosis weed reduction]. Lviv: Novyi Svit - 2000, 496 s. (in Ukrainian).

44. Shuvar, I. A., Sendetskyi, V. M. \& Bunchak, O. M. (2015) Vyrobnytstvo ta vykorystannia orhanichnykh dobryv: monohrafiia [Production and use of organic fertilizers: monograph]. IvanoFrankivsk: Symfoniia forte, 596 s. (in Ukrainian).

45. Stetsyshyn, P. O., Pyndus, V. V. \& Rekunenko, V. V. (2011) Osnovy orhanichnoho vyrobnytstva [Fundamentals of organic production]. Vinnytsia: Nova knyha, 552 s. (in Ukrainian). 
46. Yushchenko, O. M. (2017) Rozvytok orhanichnoho vyrobnytstva na Zhytomyrshchyni: dosvid PP "Haleks-Ahro" [Development of organic production in Zhytomyr region: experience of PE "Galex-Agro"]. Retrieved from: http://www.znau.edu.ua/media/ nauka_innovation/organic/Organic_20132.pdf (accessed 30 May 2019). (in Ukrainian).

47. Vasylev, V. P. \& Lesovoi, M. P. (1996) Ystoryia zashchyty rastenyi ot vredytelei y boleznei $v$ Ukrayne [The history of plant protection from pests and diseases in Ukraine]. Kyev: Ahrarna nauka, 132 s. (in Russia).

48. Voloshchuk, M. D., Petrenko, N. I. \& Yatsenko, S. V. (2014) Eroziia gruntiv Ukrainy: evoliutsiia teorii i praktyky: monohrafiia [Soil erosion of Ukraine: evolution of theory and practice: monograph]. Kyiv: TOV “Nilan-LTD”, 326 s. (in Ukrainian).

\section{Information about the author: Volodymyr Orekhivskyi, Doctor of Historical Sciences,} Director of Odessa state agricultural experimental station of National Academy of Agrarian Sciences of Ukraine 24, Mayatska road str., Khlibodarske Smt., Belyaivskyi district, Odessa region, 67667, Ukraine ORCID ID: orcid.org/0000-0002-3216-0514 